\title{
Effect of Different Processing Conditions on Antioxidant Activity of Gracilaria Edulis(Rhodophyseae) in Sri Lanka
}

\author{
Umakanthan Ganeshamoorthy \\ Department of Fisheries and Aquaculture, Faculty of Fisheries and Management, University of Ruhuna, \\ Matara. \\ ghumakanth@gmail.com
}

\begin{abstract}
Gracilaria edulis is red marine algae currently cultivated in Sri Lanka but relatively low than other country such as China and Japan. This species are used to produce drugs and healthy delicious low calorie foods because of they are primary source of secondary metabolite and to be used as natural antioxidants and antimicrobials. The Purpose of this research investigates effect of different processing conditions on antioxidant activity of G.edulis (Rhodophyseae) by hydrogen peroxide scavenging activity assay. Absorbance at $230 \mathrm{~nm}$, hydrogen peroxide scavenging assays were done. Different processed G.edulis such as fresh, steamed, boiled, dried and microwaved were extracted with methanol. Their antioxidant properties were compared to the L-ascorbic acid which used as positive control. The methanolic extracts of this red algae was prepared keeping methanol as a standard. Methanol was used as control. In minitab15 statistical software package, Paired T-Test was clearly shown the absorbance, inhibition or hydrogen peroxide scavenging activity depend on the processing conditions of the G.edulis methanol extract. This statistical test did tell about the difference between the different processing conditions of the methanol extract of the G.edulis $(p<0.05)$ and antioxidant activity and these were not independent factors such are depend on each other. Hence antioxidant activity or $\mathrm{H}_{2} \mathrm{O}_{2}$ scavenging activity was highly in boiled G.edulis, followed by fresh, microwaved, dried and steamed respectively. L-ascorbic acid was used as Positive control and its antioxidant activity was higher than dried and steamed but relatively lowers than microwaved, fresh and boiled G.edulis. Finally Boiled G.edulis sample was recorded prominent antioxidant activity due to leaching of less antioxidant compounds. In future this study is used to functional product development incorporation of dried followed by boiled G. edulis into bakery Products.
\end{abstract}

Key words: Antioxidant, scavenging, absorbance, processed, Inhibition.

\section{Introduction}

Seaweeds are commonly called as marine algae which are broadly categorized into 45000 species in worldwide (Amin, 2002). Bioactive compounds of seaweeds are having various biological activities (Bouhlar, et al., 2011, ).which are derived the secondary metabolites to screen antimicrobial and antioxidant activities (Yuan et al., 2005; Bansemir et al., 2006; Chew et al., 2008). More than 600 secondary metabolites were been isolated from Seaweeds as extensive profile source and provide wide 
range of biological activites ( Itoc \& Aorik.,1989; Pisani, et al., 1990). Among the red seaweeds particularly G.edulis consist Primary and secondary metabolities (Layse, 2011).

China and Japan people were consumed some type of seaweeds since 300 B.C. Among the countries in the world, edible seaweeds are cultivated highly by these two countries (Arasaki, 1984; Chengkui, 1984). Most of the consumable seaweeds especially under Rodophyceae, G.edulis was contained high level of dietary fiber, indigestible carbohydrates, vitamins, minerals and essential amino acids (Layase, et al., 2011). Such type of seaweeds contain bio active compounds that are used in food industries and pharmaceutical industries and used as diet in china and Japan compare to Europe and North America for cure the prostrate and breast cancer (skiboda, 2004). One or more unpaired electrons means single electrons contain in free radical molecule outer orbital. Such types of free radical are in reactive oxygen and nitrogen species. These were generated by oxidative stress brought about by free radical formulation and imbalance of body antioxidant defense system (Meenakshi, et al., 2009). Oxidative stress cause ischemic injury, cancer aging inflammation, and neurodegenerative diseases (Parkinson's and Alzheimers's). Reactive oxygen species such as nitric oxide radical, superoxide radical, peroxyl radical and hydroxyl radical form extensive oxidative damage are associated with those diseases. Such reactive oxygen species attach with RNA and DNA, Lipids and enzymes leading to cell or tissue damage and carcinogenesis and which are associated with chronic diseases such as cerebrovascular and cardiac diseases (Reaven and Witzum, 1996; Aruoma, 1999).

Seaweeds produce strong oxidizing agents and free radicals in high oxygen concentration and light environment. This is happen in photodynamic damage during metabolism period. Bioactive compounds of consumable seaweeds have protective mechanisms against the free radicals (Matsukawa, et al., 1997). Antioxidants neutralize free radicals (Rinelhof, et al., 2000). Antioxidants are found as micronutrients which are scavenged or neutralized free radicals for protect from free radical induced diseases. (Chanda, 2010). Bioactive substances extract from G.edulis can have ability to destroy free radicals. This protection was measured by presence of antioxidants. This effect could be evolved by metal ion chelators, quenchers, free radical scavengers, hydrogen donating compounds. (Amin and Hong, 2002). In the family Rhodophyta, especially G.edulis are the major Sri Lankan agarophytes and to be considered as very important species for biotechnologies industries. This species is used to prepare agar and agarose. Antimicrobial activities, antiviral, antifungal and antioxidant activities have been screened in green, brown and red algae (De souza, et al., 2007; smith, 2004., Madhusudan, et al., 2011). The objective of this present research is used to study the effect of different processing conditions on antioxidant activity of G.edulis species.

Oxidative deterioration is taken place in lipid form of phospholipid and tryglyceride and then generated food quality deterioration, off flavours rancidity and other reactions. Light, heat, metalion/metalloprotein and ionizing radiation are initiated autooxidation. Lipoxygenaseis process is taken by three steps such as initiation, propogation and termination. Which three steps are occurred in autooxidation process (Shihidi \& Naczk, 2004).

General scheme for autooxidation of polyunsaturated lipids: 
Umakanthan Ganeshamoorthy; Effect of Different Processing Conditions on Antioxidant Activity of Gracilaria Edulis(Rhodophyseae) in Sri Lanka. Journal of Biomedical Engineering and Medical Imaging, Volume 6, No 5, October (2019), pp 64-90

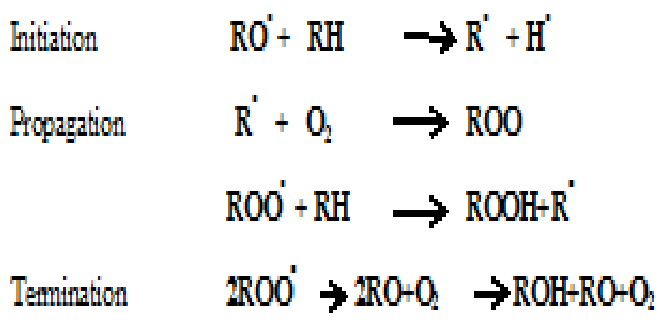

Human physiopathologies involve with reactive oxygen species (Shahidi and Naczk, 2004). Oxidative stress is a reason to form many multifactorial diseases such as inflammatory disorders (Bodamyali, et al., 2000) especially cancers (Kawanishi, et al., 2002) cardiovascular diseases (Sachidanandame, et al., 2005). This oxidative stress caused by productions of oxidants including antioxidant systems and ROS. ROS is causing diseases such as inflammation, cancer, cardiovascular disease, artherosclerosis, arthritis, aging, diabetes and parkinsonism. In seaweeds, Phenolic phytochemicals content inhibit autoxidation of unsaturated lipids and formation of oxidized low-density lipoprotein (LDL) for protecting the body from cardiovascular diseases (Amic, et al., 2003). Therefore high level of Phytochemical content of any food may protect the human body (Chandini, et al., 2008).Oxidative alteration of bioactive molecules involve with mechanism of ROS. Such bioactive molecules are carbohydrates, nucleic acids, proteins and lipids along with the inflammatory response and modulation of gene expression. (Laguerre, et al., 2007). Nitric oxide radical $\left(\mathrm{NO}^{\circ}\right)$, hydroxyl radical $\left(\mathrm{OH}^{\circ}\right)$, Superoxide radical $\left(\mathrm{O}^{\circ} 2^{-}\right)$, and peroxyl radical ( $\left.\mathrm{ROO}\right)$ are ROS. These molecules were attacked molecules such as enzymes, proteins, DNA, RNA and lipids, leading to cell damage associated with carcinogenesis aging, and atherosclerosis ( Fisch, et al., 2003; Shon, et al., 2003; Nakamura, et al., 2003; Valentao, et al.,2002). Normally antioxidants found compounds are protecting the body against ROS. During the photosynthesis process in seaweed molecular oxygen evolved in the presence of solar light. This molecular oxygen reaches highest concentration level during that process. In the presence of heat or UV radiation of sunlight, oxygen activate into toxic ROS. Marine algae antioxidants have special defense mechanisms against ROS for reduce their concentration. (Lu and Foo, 1995). Antioxidants have different mechanisms for scavenging free radicals, binding metal ions, decomposing hydroperoxides and peroxides among others (Moure, et al., 2001). Free radical inactive by natural good antioxidants highly.

Table:1* Different mechanism of antioxidant activity

\begin{tabular}{|c|c|c|}
\hline Antioxidant class & Examples of antioxidants & Mechanism of antioxidant activity \\
\hline Proper antioxidant & $\begin{array}{l}\text { Phenolic compounds, tocopherols, } \\
\text { Flavanoids }\end{array}$ & Inactivating lipid free radicals \\
\hline Hydroperoxide stabilizers & Phenolic compounds & $\begin{array}{l}\text { Preventing decomposition of } \\
\text { hydroperoxides into free radicals }\end{array}$ \\
\hline $\begin{array}{l}\text { Substance } \\
\text { hydroperoxides }\end{array}$ & Protein, aminoacids & $\begin{array}{l}\text { Reducing hydroperoxides in a non- } \\
\text { radical way. }\end{array}$ \\
\hline Singlet oxygen quenchers & carotenoids & $\begin{array}{l}\text { Transforming singlet oxygen into } \\
\text { triplet oxygen }\end{array}$ \\
\hline Synergists & Citric acid, ascorbic acid & $\begin{array}{l}\text { Promoting activity of proper } \\
\text { antioxidants }\end{array}$ \\
\hline Metal chelation & Flavanoids, Phosphoric & $\begin{array}{l}\text { Promoting activity of proper } \\
\text { antioxidants }\end{array}$ \\
\hline
\end{tabular}


Many researchers were stated as seaweeds are rich sources of natural antioxidant compounds (Lim, et al., 2002; Duan, et al., 2006; Kuda, et al., 2007; Cox, et al., 2010). Plant-derived structurally related antioxidants such as Chlorophylls, carotenoids, tocopherol derivatives such as vitamin $\mathrm{E}$ and related isoprenoids were also found in some marine organisms in naturally (Takamatsu, et al., 2003). Antioxidant activity may evolve by niacin, flavonoids, ascorbic acid and pigments such as chlorophylls, carotenoids, and vitamins and vitamin precursors including, thiamine, $\beta$-carotene $\alpha$-tocopherol and phenolics such as hydroquinones, polyphenolics, and phospholipids particularly phosphatidylcholine, terpenoids, peptides, and other antioxidative substances in seaweeds which are suppressed oxidation process directly or indirectly (Shahidi, 2008). Micronutrients found in red green and brown algae and act as natural antioxidants (Chanda, 2010). Phenolic compounds of seaweeds were available as benzene ring substituted by at least one hydroxyl (Manach, et al., 2004; Duan, et al., 2006). These phenolic compounds of antioxidant activities were worked as chelating metal ions and improving the antioxidant endogenous system by preventing radical formation (Al-Azzawie and Mohamed-Saiel, 2006). flavanones, flavones, flavononols, flavonols, flavan-3-ols,tocopherols, chalcones, tannins, lignins and phenolic acids are commonly polyphenols found in seaweeds. Which are source of antioxidant activities to reduce the use of BHT and BHA and natural antimicrobial (Shukla, et al., 1997).

Free radicals are caused oxidative damage or oxidative stress. These free radicals such as reactive oxygen and nitrogen species contain one or more unpaired electrons in outer orbitals and produce Parkinson disease, aging, cancer, ischemic injury, alzheimers and inflammation. Free radicals and Oxygen species oxidize protein, nucleic acid, DNA and lipid (Vadlapadi, et al., 2010). These free radicals are reduced by natural antioxidants (Akoh and Min, 1997). Phenolic acid, Carotenoids, Phytoestrogens, phyruvate, vitamin $\mathrm{E}$ and Vitamin $\mathrm{C}$ are antioxidants to neutralize free radicals from different sources (Meenakshi, et al., 2009). Naturally available antioxidants protect human from oxidative damage and increase the shelf life of foods (Chandini, et al., 2008).Tannins of natural phenolic metabolite is commonly found in marine and terrestrial plants and categorized into hydrolysable and condensed compounds (Haslam, 1989; Waterman and Mole, 1994). Phlorotannins is under Tannin compounds group. Phlorotannins derived from marine plant is having unique eight interconnected rings molecular structure and possess antioxidant activity. In marine algae phlorotannins synthesize in the acetate-malonate pathway by the polymerization of phloroglucinol (1, 3, 5-trihydroxybenzene) monomer units. (Ragan and Glombitza, 1986; Waterman and Mole, 1994; Arnold and Targett, 1998). Naturally available antioxidants in G.edulis such as flavonoid, phenolic acid and poly phenol retard or inhibit oxidative stress that leads to degenerative similar diseases (Miller, H.E. \& Rinelhof, et al., 2000).

Decomposition of hydroperoxides into free radicals prevent by Flavonoids and Phenolic compounds. Phenolic compounds were proper antioxidants. Such Carotenoids molecules reduce hydroperoxides by a non-radical way. Natural antioxidants reduce toxic causing Butylated hydroxytoluene (BHT), Butylated hydroxyanisole (BHA) (Duan, et al., 2006). Phenolic compounds, flavonoids, alkaloid, saponins and carotenoids are natural antioxidants widely distributed in the G.edulis. Among these bioactive substances especially Phenolic components and flavonoids contain structural requirements for free radical scavengers and natural food antioxidants (Bandoniene and Murkovic, 2002). Which act as a protective mechanism against oxidative damage of living cell (Vimala, et al., 1999) and also increases the shelf-life of foods (Schwarz, et al., 2001). 
Umakanthan Ganeshamoorthy; Effect of Different Processing Conditions on Antioxidant Activity of Gracilaria Edulis(Rhodophyseae) in Sri Lanka. Journal of Biomedical Engineering and Medical Imaging, Volume 6, No 5, October (2019), pp 64-90

Environmental stress and microbes affects are protected by protective mechanisms of phenolic compounds (Harbourne, 1994; Herrmann, 1989; Wallace and Fry, 1994). Flavonoid is one of largest group of phenolic compounds. This Flavonoid has free radical scavenging activities (Kahkonen, et al., 1999). Because of radicals planar conformation offers extended electronic delocalization between adjacent rings, Flavonols were exposed antioxidant activity while study the quantum mechanical (Russo, et al., 2000). Flavanol was present in G.edulis. (Umakanthan, et al., 2016).

Antioxidant activity or inhibition activity or radical scavenging activity of antioxidants were measured by several analytical methods such as oxidation rate, $\%$ of the reagents used and inhibition against free radicals like hydroxyl radical(OH), 1,1-diphenyl-2-picrylhydrazyl(DPPH), hydrogen donating compounds metal chelators (Amin and Hong, 2002). While consider this method for measure antioxidant activity, primary radicals are reduced to non-radical chemical compounds into oxidize antioxidant radicals by donating hydrogen radicals (Jadhav, et al., 1995;Yamaguchi, et a., 1998; Hwang. Pai. Aa, 2010; devi, et al., 2008).

Antioxidant activities or scavenging activities depend on active group presence in sample. These antioxidant activities vary with presence of active group, kind and their position. In the presence of free radicals, antioxidants can be shown two types of mechanisms.

1. $\mathrm{R}^{\circ}+\mathrm{ArOH} \rightarrow \mathrm{RH}+\mathrm{ArO}^{\circ}$

2. $\mathrm{R}^{\circ}+\mathrm{ArOH} \rightarrow \mathrm{R}+\mathrm{ArOH}^{+}$

In the first mechanism, antioxidant activity measure by $\mathrm{OH}$ bond dissociation energy. Antioxidant activity of ArOH loses its hydrogen atom and become a radical. This is reaction is more suitable to explain DPPH scavenging activity. $\mathrm{OH}$ bond dissociation energy inversely proportional to DPPH scavenging activity and antioxidant activity (Wright, et al., 2001). Lower bond energies means weaker $\mathrm{OH}$ bond will be inactivated free radical easily due to weaker $\mathrm{OH}$ bond dissociation energy lose its hydrogen atom easily. This losing $\mathrm{H}$ atom reacts with free radical for free radical inactivation. In the second mechanism, antioxidant activity explains by $\mathrm{H}_{2} \mathrm{O}_{2}$ scavenging activity or $\mathrm{H}_{2} \mathrm{O}_{2}$ assay. Where $\mathrm{ArOH}$ is antioxidant and that gives an electron to form radical cation. Electron donor ability is proportional to $\mathrm{H}_{2} \mathrm{O}_{2}$ scavenging or antioxidant activity (Wright, et al., 2001).

Over last two decades natural antioxidant molecules has been interested for research studies. Exogenic antioxidants derived from foods are very significantly to counteracting oxidative stress. Marine plants are the major source of these antioxidants in the form of phenolic compounds such as flavonoid, carotenoid, alkaloid and saponins (Laguerre, et al., 2007). In recently among the most of, Algae, Tea, herbs, terrestrial pants, marine plants and seeds are researched to identify as natural antioxidants. But vast research knowledge has not been gained into the effect of different processing conditions on antioxidants activity resultant from G.edulis. Previous my research was revealed the antioxidant activity of G.edulis but not clearly state their effect of different processing conditions on antioxidant activity of G.edulis.

Seaweeds based foods have been eaten raw or after processing treatment by human in Asian countries since from ancient times. This processing techniques were been varied in different parts of world such as 
steaming, boiling, drying and microwaving where number of changes were been happen in its physical characteristics and chemical composition (Zhang and Hamauzu, 2004). While processing techniques take place in vegetable prior to consumption, phytochemicals and its concentrations and detrimental factors were been considered as prime factor to alter health related quality. In wet thermal treatment, denaturation of enzymes can catalyze breakdown of phytochemicals and nutrients. The heat processing technique causes the reduction of phtochemical content due to thermal destruction or leaching (Rungapamestry, et al., 2007).Nowadays food industry and consumers use various preservation techniques and methods. Food processors, food safety regulators and regulatory agencies are continuously disturbed with increase of illness caused by some pathogenic and spoilage microorganisms in foods. Hence currently Consumers are demanding minimally processed natural, fresh and safety foods that contain natural antioxidant and synthetic preservatives to protect the body from those multifactorial diseases. This is the reason behind food industries are more concerned in the research for discover alternative natural antioxidant (Shan, et al., 2007). Research results on the effects of processing on the antioxidant compounds in seaweeds have been inconclusive. While doing some research in vegetables their results revealed no change or an increase in antioxidant activity (Gahler, et al., 2003; Turkmen, et al., 2005) and some another research was shown deterioration activity after thermal treatment (Ismail, et al., 2004; Zhang and Hamazu, 2004).The phytochemicals in seaweeds are important for human health. Natural antioxidant compound of red algae especially G.edulis was been studied. Therefor seaweed processing technique thermally prior to consumption which matter is needed to investigate how the processing techniques affect the antioxidant activity of G.edulis. Bioactive substances or Phytochemicals are richly available in seaweed foods. That is responsible for antimicrobial and antioxidant activity. Previously Quantities of the biochemical compounds in seaweeds have been studied by many researchers (Duan et al., 2006; Chandini et al., 2008; Cox et al., 2010). Most of the science researchers were screened antioxidant activity of seaweed varieties (Gonzalez del Val, et al., 2001; Ganesan, et al., 2008; Plaza, et al., 2009). G.edulis is commonly found in Sri Lanka especially edible seaweed widespread in Kalpitiya, Puttalam. However there is no further information about effect of different processing conditions on antioxidant activity of seaweed extracts from Sri Lanka especially widespread of red seaweed G.edulis in Kalpitiya, Puttalam. This research was determine most favorable processing conditions could be used to exhibit high antioxidant compounds for making most potent functional food. The main purpose of this research chapter was used to study the effect of different processing conditions on the antioxidant activity of $G$.edulis by hydrogen peroxide scavenging activity.

\section{Materials and Methodology}

\subsection{Sample collection:}

G.edulis samples from Kalpitiya, Puttalam were collected and transported to the lab in $0^{\circ} \mathrm{C}$ by keeping in an insulated box for assess the different processing conditions on antioxidant activities of G.edulis. Those particular sample specimens were identified at Department of Zoology, Eastern University, Sri Lanka.

\subsection{Preparation of methanol residual extracts of G.edulis}

The G.edulis samples were rinsed thoroughly in fresh water and then distilled water used to remove dirt mud, particles and other epiphytes. G.edulis samples were prepared as fresh, dried for 12 hours, Boiled at $100^{\circ} \mathrm{C}$, steamed and microwaved $900 \mathrm{~W}$ in $12-15$ minutes to assess the different processing conditions 
Umakanthan Ganeshamoorthy; Effect of Different Processing Conditions on Antioxidant Activity of Gracilaria Edulis(Rhodophyseae) in Sri Lanka. Journal of Biomedical Engineering and Medical Imaging, Volume 6, No 5, October (2019), pp 64-90

on antioxidant activities of G.edulis. After that each samples were blended. Then that $10 \mathrm{grams}$ of blended sample was mixed with $100 \mathrm{ml}$ of methanol solvent and maintained in shaking condition for $24-48$ hours. After that in hot water bath methanol solvents were evaporated at its boiling temperature. Finally each G.edulis methanol residual extract was taken to measure the antioxidant activities.

\subsection{Determination of hydrogen peroxide scavenging}

The different processed conditions of G.edulis sample antioxidant ability were measured by hydrogen peroxide scavenging activity according to the method of (Ruch, et al., 1989). The reaction mixture was been $1 \mathrm{ml}$ of hydrogen peroxide solution (35.4 mM) and different processing conditions of methanol extract of G.edulis. Sum of the reaction mixture was $3 \mathrm{ml}$. at $230 \mathrm{~nm}$ hydrogen peroxide absorption was read within 3 min against a blank solution that contained ethanol without hydrogen peroxide. Ascorbic acid was used as reference standard. Experiment was done in six times to each different processed conditions sample. Spectrophotometer ( $\operatorname{Dr} 5000)$ was used to measure the absorption.

$\%$ scavenging of hydrogen peroxide effect=(Ac-As/Ac)*100

where $A c=$ control absorption, $A s=$ absorbance of sample absorption.

(hydrogen peroxide solution in ethanol without sample for used as control).

\subsection{Statistical analysis:}

Microsoft excel 2010 version and Minitab15 (Minitab 15, 2007) software package were used for statistical analysis. The paired T-test was used for comparison of mean values. Pearson correlation was tested to find significance relationship between samples at different processed conditions and percentage of $\mathrm{H}_{2} \mathrm{O}_{2}$ scavenging activity. Here $P$ value of $<0.05$ was considered as statistically significant.

\section{Results and Discussion}

Table1:Absorbance of different processed G.edulis by spectrophotometer (Dr5000)

\begin{tabular}{ll}
\hline \multicolumn{1}{c}{$\begin{array}{c}\text { Samples at } \\
\text { concentration } 100 \\
\mu \mathrm{g} / \mathrm{ml}\end{array}$} & Absorbance \\
\hline $\begin{array}{l}\text { Fresh G.edulis } \\
\text { methanol extract }\end{array}$ & $0.02 \pm 0.001$ \\
Methanol(Control) & $0.128 \pm 0.001$ \\
L-Ascorbic acid & $0.039 \pm 0.001$ \\
steam G.edulis & $0.06 \pm 0.009$ \\
Boiled G.edulis & $0.01 \pm 0.005$ \\
Dried G.edulis & $0.04 \pm 0.009$ \\
microwaved G.edulis & $0.023 \pm 0.001$ \\
\hline
\end{tabular}


Table2: Hydrogen peroxide scavenging activity of different processed G.edulis

\begin{tabular}{lc}
\hline $\begin{array}{c}\text { Samples at } \\
\text { concentration } 100 \\
\mu \mathrm{g} / \mathrm{ml}\end{array}$ & $\begin{array}{c}\text { \%of Hydrogen } \\
\text { peroxides scavenging } \\
\text { activity }\end{array}$ \\
\hline $\begin{array}{l}\text { Fresh G.edulis methanol } \\
\text { extract }\end{array}$ & 84.38 \\
L-Ascorbic acid & 69.53 \\
steam G.edulis & 53.13 \\
Boiled G.edulis & 92.19 \\
Dried G.edulis & 68.75 \\
microwaved G.edulis & 82.03 \\
\hline
\end{tabular}

\subsection{Effect of different processing conditions on $\mathrm{H}_{2} \mathrm{O}_{2}$ radical scavenging activity}

\section{Paired T-Test and Cl: Absorbance, Hydrogen peroxide scavenging ac}

Paired T for Absorbance - Hydrogen peroxide scavenging ac

$\begin{array}{lrrrr} & \mathrm{N} & \text { Mean } & \text { StDev } & \text { SE Mean } \\ \text { Absorbance } & 7 & 0.0 & 0.0 & 0.0 \\ \text { Hydrogen peroxide scaven } & 7 & 64.3 & 31.1 & 11.8 \\ \text { Difference } & 7 & -64.2 & 31.1 & 11.8\end{array}$

95\% CI for mean difference: (-93.0, -35.4)

$\mathrm{T}$-Test of mean difference $=0($ vs not $=0): \mathrm{T}$-Value $=-5.46 \mathrm{P}$-Value $=0.002$

\section{Correlations: Absorbance, Hydrogen peroxide scavenging ac}

Pearson correlation of Absorbance and Hydrogen peroxide scavenging ac $=-0.988$ $\mathrm{P}$-Value $=0.000$

Graph:1different processed G.edulis sample Vs absorbance

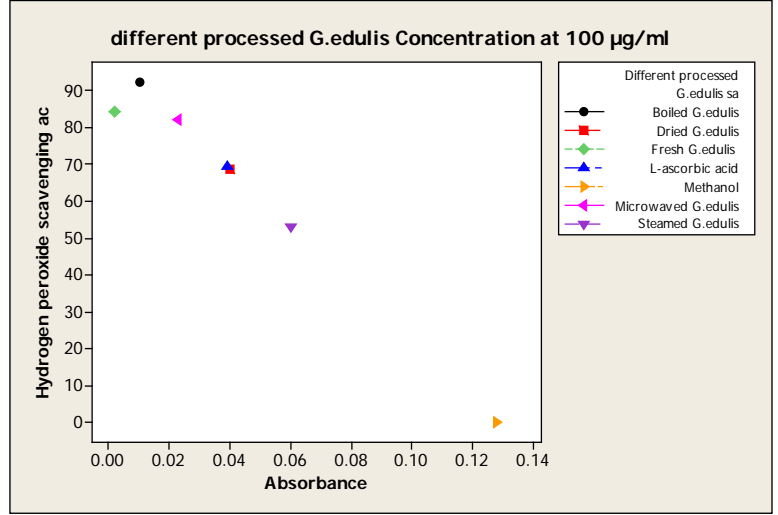

Graph:2 Hydrogen peroxide scavenging activity Vs Absorbance

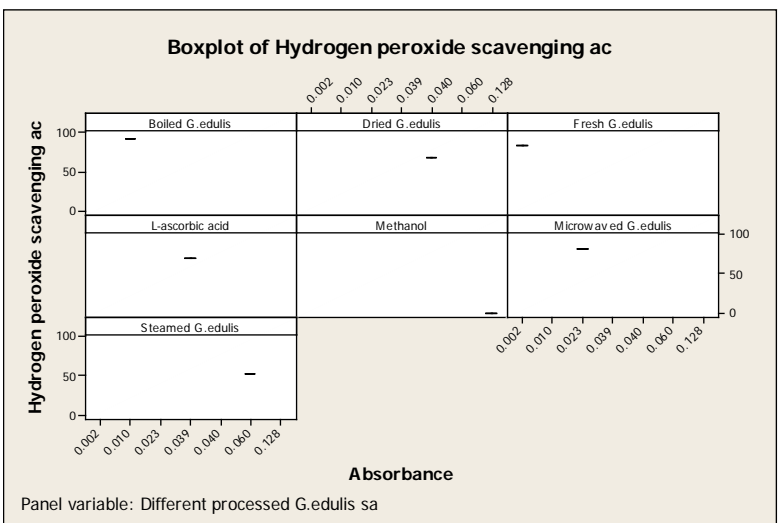


Umakanthan Ganeshamoorthy; Effect of Different Processing Conditions on Antioxidant Activity of Gracilaria Edulis(Rhodophyseae) in Sri Lanka. Journal of Biomedical Engineering and Medical Imaging, Volume 6, No 5, October (2019), pp 64-90

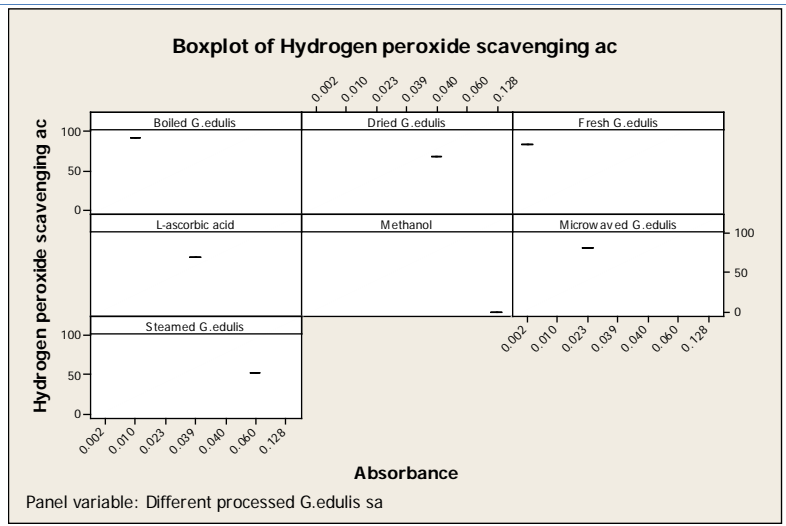

Absorbance of different processed G.edulis at $230 \mathrm{~nm}$ was clearly shown in table $1 . \mathrm{H}_{2} \mathrm{O}_{2}$ free radical scavenging activity of those samples G.edulis results were resulted in table 2 . That free radical scavenging activity results were varied between $53.125 \%$ to $92.1875 \%$ at $100 \mu \mathrm{g} / \mathrm{ml}$ extract and sample boiled at 100 ${ }^{\circ} \mathrm{C}$ being most effective. There were significant differences $(P<0.05)$ for all different processing conditions in $\mathrm{H}_{2} \mathrm{O}_{2}$ free radical scavenging activity. In heat process, $\mathrm{H}_{2} \mathrm{O}_{2}$ radical scavenging activity was slightly led to increase from $53.125 \%$ to $92.1875 \%$ while absorbance led to a significant decrease $(P<0.05)$ in $100 \mu \mathrm{g} / \mathrm{ml}$ extract.

The table 1.1 was shown the $\mathrm{H}_{2} \mathrm{O}_{2}$ radical scavenging activity that means antioxidant activity were presenced in all processed G.edulis sample. Pearson correlation Graph 1 Antioxidant properties of all processed sample were been correlated to its absorbance. That stated antioxidant compounds were presence of those sample. Here electron donations or hydrogen donor was occurred efficiently. In 45 minutes steamed sample, $\mathrm{H}_{2} \mathrm{O}_{2}$ radical scavenging activity $(P<0.05)$ was recorded very lowest such as 53.125\%. In 12 hrs drying pre-treatments $\mathrm{H}_{2} \mathrm{O}_{2}$ radical scavenging activity was $68.75 \%$. In microwaved, $\mathrm{H}_{2} \mathrm{O}_{2}$ radical scavenging activity was $82.03125 \%$ at $900 W . \mathrm{H}_{2} \mathrm{O}_{2}$ radical scavenging activity was recorded highest in boiled G.edulis sample at $100^{\circ} \mathrm{C}$ such as $92.1875 \%$. Boiled G.edulis was shown highest $\mathrm{H}_{2} \mathrm{O}_{2}$ radical scavenging activity that revealed boiled G.edulis was recorded comparatively highest antioxidant properties than other processed G.edulis sample due to leaching of less potent constituents into boiling water however microwaved and steamed samples were not in direct contact with water for such leaching to occur. Antioxidant activity of Boiled G.edulis was recorded highly followed by fresh, microwaved, dried and steamed. Steamed G.edulis was lowest antioxidant activity than others. Scavenging effects of the steam dried, microwaved, fresh and boiled were increased up to $53.125 \%, 68.75 \%, 82.03125 \%, 84.375 \%$ and $92.1875 \%$ at $100 \mu \mathrm{g} / \mathrm{ml}$ extracts. In Graph $1 \& 2$ There was strong negative correlation between scavenging ability on $\mathrm{H}_{2} \mathrm{O}_{2}$ radical and absorbance of total antioxidant compounds of $G$.edulis and positive correlation between antioxidant activity and the antioxidant compounds presence in G.edulis. Excellent antioxidant effect was screened at boiled one.

\section{Discussion}

Nearly 150,000 seaweeds were found in the intertidal zones of ocean environment (Amin, 2002). Especially in Asian countries such as Japan, Korea and china are used as most ecologically important macro algae for food. However genus (Gracilariales, Rhodophyta) was an important seaweed group with more than 300 species of which 160 have been known and accepted taxonomically (Layase, 2011). Usually 
green, brown and red algae were found in subtropical and tropically which are synthesized bioactive compounds such as primary metabolites with antibiotic ability (Kayatzi, 2012).

Natural antioxidants and anti-properties of marine algae were reported in several research studies (Chew, 2008). The marine algae can grow in harsh environment with combination of oxygen concentration which is the reason formation of strong oxidizing agents and free radicals but they have special mechanisms and compounds for seldom suffer any serious photodynamic damage during metabolism (Matsukawa et al.,1997). Free radicals can cause cancer, cardiovascular and neural disorders Alzheimer's disease in human. Dietary antioxidants especially G.edulis foods protect the human body from these types of diseases via trap or inactivation the free radicals. So Antioxidant compounds were used as health protecting factor for reduce the risk for chronic diseases such as cancer and heart diseases. Such antioxidant nutrients protect from free radicals for improving quality of life by prevent onset of degenerative diseases.

Edible seaweeds, fruit, vegetable and whole grains contain main source of natural antioxidants. Most of the antioxidants in a diet derived from plants such natural antioxidants are phenolic acids, phytate, phytoestrogens, carotenes, vitamin $\mathrm{C}$ and vitamin $\mathrm{E}$. which were consisted wide variety of physical and chemical properties and high potential to reduce that type of diseases. For example mono- phenols are weak antioxidants and gallates are strong antioxidants. G.edulis species have such type of antioxidant compounds. Antioxidant compounds were inactivated free radicals. In biological system, existing oxygen species and highly reactive free radicals were oxidized nucleic acids, DNA, proteins and lipids to cause degenerative diseases (Miller and Rigelhof, et al., 2000). Marine algae especially red algae G.edulis contain antioxidant compounds like flavonoids alkaloid and phenol scavenge free radicals such as hydroperoxide or lipid Peroxyl and peroxide for inhibit the oxidative mechanisms that lead to Prevent degenerative diseases. This research belongs to effect of different processing conditions such dried, steam, boiled and microwaved of G.edulis on antioxidant ability were investigated.

In recently various methods are used to analyze antioxidant activity such as oxygen radical absorbance capacity (ORAC) assays and enhanced chemiluminescence assays. These methods are needed special equipment and good technical skills. ABTS [2,2'-azinobis(3-ethylbenzothiazoline-6-sulfonic acid)] radical cation is used to analyze relative radical-scavenging activities of phenolics and flavonoids through their Prior. In the presence of the antioxidant Thiobarbituric acid-reactive-substances (TBARS) (1) or malondialdehyde (MDA) assays to estimate the peroxidation of lipids in membrane and biological systems. Which is time consuming method due to oxidation of a Substrate depend on pressure matrix and temperature and may not be practical when large numbers of samples are involved. Results will be varied depending on the specific free radical being used as a reactant in different antioxidant assay. Hydrogen peroxide assay measure the radical scavenging activity of antioxidants presence in sample against free radicals like $\mathrm{H}_{2} \mathrm{O}_{2}$ radical, hydroxyl radical $\left(\mathrm{OH}^{\cdot}\right)$, superoxide anion radical $\left(\mathrm{O}_{2} \cdot{ }^{\cdot}\right.$ ), peroxyl radical (ROO). Antioxidant activity measure by using trap or inactivate free radical which is relatively straightforward to perform antioxidant ability. $\mathrm{H}_{2} \mathrm{O}_{2}$ scavenging activity gives overall antioxidant capacity of sample for understand the functional properties of food which method is rapid, simple and inexpensive best method. The $\mathrm{H}_{2} \mathrm{O}_{2}$ scavenging activity of G.edulis methanol extract was tested by using $\mathrm{H}_{2} \mathrm{O}_{2}$ free radical unlike superoixide anion and hydroxyl radical because such are laboratory generating free radical. G.edulis methanol extracts were free radical scavenger or free radical inhibitors and it was used as primary antioxidants. G.edulis was shown scavenging activity in $\mathrm{H}_{2} \mathrm{O}_{2}$ radical due to presence of active substances 
Umakanthan Ganeshamoorthy; Effect of Different Processing Conditions on Antioxidant Activity of Gracilaria Edulis(Rhodophyseae) in Sri Lanka. Journal of Biomedical Engineering and Medical Imaging, Volume 6, No 5, October (2019), pp 64-90

including flavanols, pigments, alkaloids and some other phenolic compounds. Here electron donating ability was scavenged $\mathrm{H}_{2} \mathrm{O}_{2}$ as possible mechanisms for their antioxidant ability (Wright2 mechanism). The inhibition rate or scavenging activity was varied depend on the processing conditions. Antioxidants in algal foods are water soluble, insoluble, fat soluble which bound to cell wall but not free available to react with $\mathrm{H}_{2} \mathrm{O}_{2}$. However different processed G.edulis samples were reacted with different rates. The antioxidant activity was expressed in absorbance of sample and its control at the endpoint. During the period $\mathrm{H}_{2} \mathrm{O}_{2}$ react with G.edulis methanolic extract. Their antioxidant activity was increased with the time and stops at certain time. Various antioxidant analyses are limited to those compounds soluble in selected solvent. Methanol was the best extraction solvent (Kolanginathan., 2009). Whole sample was allowed to react with $\mathrm{H}_{2} \mathrm{O}_{2}$ in sufficient time because reaction was slowly in week antioxidant.

While consider modulation of free radicals by natural antioxidants there are two type of antioxidants such as enzymatic antioxidants and nonenzymatic antioxidants which were modulated the free radical reactions. Enzymatic antioxidant mechanisms protect the human body from ROS (Koruk, et al.,2004). Antioxidant enzymes reduce $\mathrm{H}_{2} \mathrm{O}_{2}$ and lipid hydroperoxide level, which are used to maintain structure and function of cell membranes and lipid hydroperoxide.Examples of the enzymatic antioxidants (Fig.3, are CAT, GSHPx, SOD, and peroxiredoxin I-IV (I-IV).
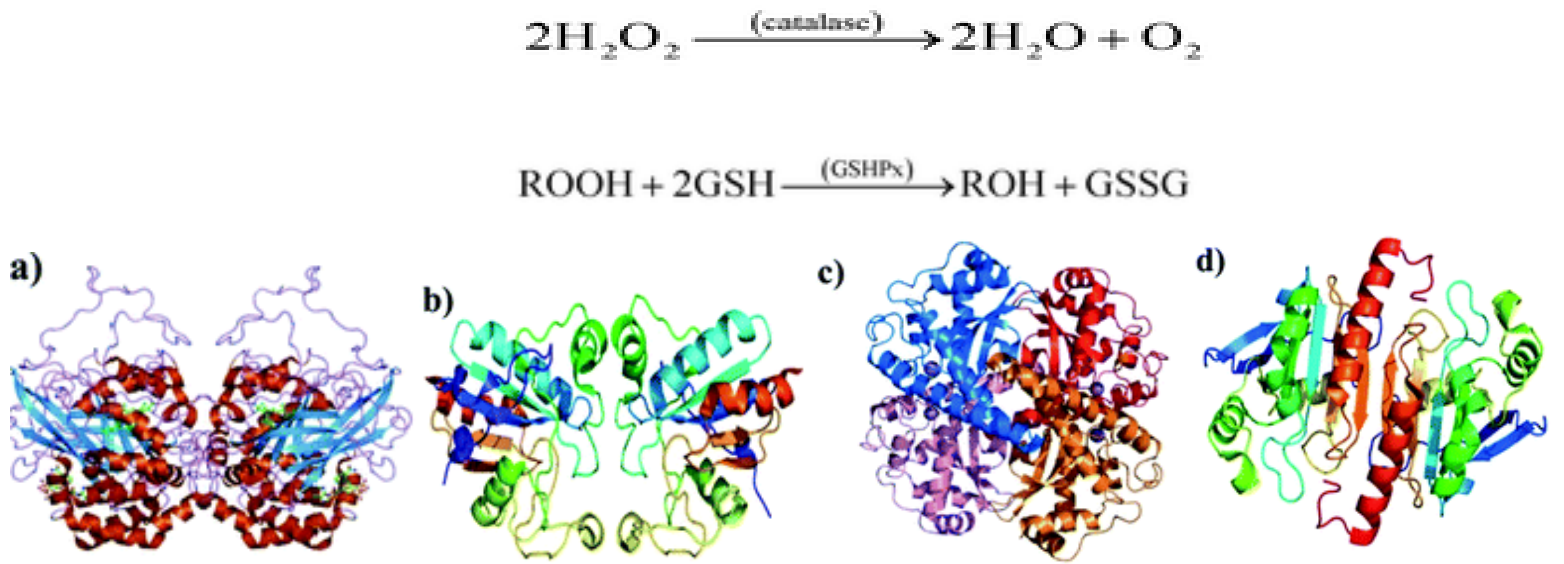

Figure. 3 (a) CAT, (b) GSHPx, (c) SOD, and Prx-I. Nimse, S.B and Pal, D,_5 online Article, image, viewed 2015, http://pubs.rsc.org/en/journals/journal/RA?issueid=RA005035 
Table 3 Enzymatic antioxidants, their cellular locations and the reactions they carry out

\begin{tabular}{|c|c|c|c|}
\hline Substrate & Enzymatic antioxidant & Cellular location & Reaction \\
\hline $\mathrm{H}_{2} \mathrm{O}_{2}$ & CAT & Peroxisomes cytosol & $2 \mathrm{H}_{2} \mathrm{O}_{2} \rightarrow \mathrm{O}_{2}+\mathrm{H}_{2} \mathrm{O}$ \\
\hline $\mathrm{H}_{2} \mathrm{O}_{2}$ & GSHPx & Cytosol & $\begin{array}{l}\mathrm{H}_{2} \mathrm{O}_{2}+\mathrm{GSH} \rightarrow \mathrm{GSSG} \\
+\mathrm{H}_{2} \mathrm{O}\end{array}$ \\
\hline $\mathrm{O}_{2}^{--}$ & $\mathrm{Mn} / \mathrm{Cu} / \mathrm{Zn} \mathrm{SOD}$ & $\begin{array}{ll}\text { Mitochondrial matrix } \\
\text { (Mn SOD) } \\
\text { (Cu/Zn SOD) }\end{array}$ & $\mathrm{O}_{2}^{\cdot-} \rightarrow \mathrm{H}_{2} \mathrm{O}_{2}$ \\
\hline $\mathrm{H}_{2} \mathrm{O}_{2}$ & Prx-I & Cytosol & $\begin{array}{l}\mathrm{H}_{2} \mathrm{O}_{2}+\mathrm{TrxS}_{2} \rightarrow \\
\operatorname{Trx}(\mathrm{SH})_{2}+\mathrm{H}_{2} \mathrm{O}\end{array}$ \\
\hline
\end{tabular}

In the presence of metal ion co factors, $\mathrm{O}_{2}{ }^{--}$catalytically convert into $\mathrm{H}_{2} \mathrm{O}_{2}$ and Oxygen while SOD's located in the mitochondria and cytosol (Gough et al., 2011). In the presence of CAT enzyme in the peroxisome $\mathrm{H}_{2} \mathrm{O}_{2}$ convert into to water and oxygen (Stone, et al., 2006). GSHPx is found in human tissue and cytoplasm as extracellular component which has strong activity against hydroperoxides, fatty acid and $\mathrm{H}_{2} \mathrm{O}_{2}$ which enzyme convert the $\mathrm{H}_{2} \mathrm{O}_{2}$ into the water(Arthur, et al., 2000). Peroxyredoxin enzyme was catalyzed the reduction of peroxynitrite $\left(\mathrm{ONOO}^{-}\right), \mathrm{H}_{2} \mathrm{O}_{2}$ and organic hydroperoxides. The antioxidant enzymes consist a vital role for prevention of oxidative damage. SOD, GSHPx and CAT were given synergistic effect in the scavenging of $\mathrm{O}_{2} \cdot{ }^{--}$(Valko, et al., 2007). Scheme 1

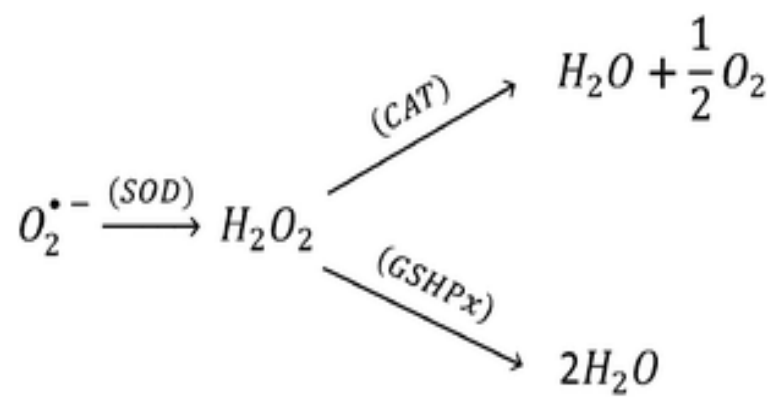

Scheme1: Radical scavenging activity of SOD, GSHPx and CAT

Most of biochemistry research article illustrate enzymatic antioxidants and their mechanisms (Mates, et al.,2000). This paper was focused only nonenzymatic antioxidants which are two types synthetic antioxidants and natural antioxidants. However this research paper was focused on natural antioxidants.<smiles>CCCCCC1(C)CCc2c(C)c(O)c(C)c(C)c2O1</smiles>

Picture:1 Vitamin E 1

Efficient lipid soluble antioxidant Vitamin $\mathrm{E}$ ( $\alpha$-tocopherol) chemical structure was shown in picture1. This is worked as chain breaker during lipid peroxidation in cell membranes. Intercept lipid peroxyl radicals 
Umakanthan Ganeshamoorthy; Effect of Different Processing Conditions on Antioxidant Activity of Gracilaria Edulis(Rhodophyseae) in Sri Lanka. Journal of Biomedical Engineering and Medical Imaging, Volume 6, No 5, October (2019), pp 64-90

$\left(\mathrm{LOO}^{\circ}\right)$ and to end up the lipid peroxidation chain reactions were done by this antioxidant (Morliere, et al., 2012).

$$
\mathrm{LOO}^{\circ}+\alpha \text {-tocopherol-OH } \rightarrow \mathrm{LOOH}+\alpha \text {-tocopherol-O }
$$

Tocopheroxyl radical is insufficiently reactive to initiate lipid peroxidation itself which is relatively stable good antioxidants (Witting, et al.,1997).Vitamin E scavenge lipid peroxyl radicals in vivo as well as in vitro systems. This antioxidant in vivo is not an efficient scavenger to alkoxyl radicals ('OR) and'OH (Morliere, et al., 2012).

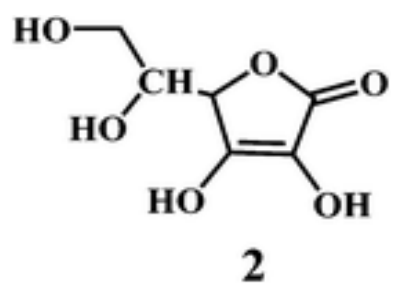

Picture: 2 Vitamin C 2,

Vitamin $\mathrm{C}$ is ascorbic acid and used as positive control. This water soluble antioxidant has ability to scavenge $\mathrm{H}_{2} \mathrm{O}_{2}$ free radical and also activates vitamin $\mathrm{E}$ in cell membranes in combination with compounds or GSH ability to donate reducing equivalents (Oh, et al., 2010). by giving an electron to the lipid radical in order to terminate the lipid peroxidation chain reaction, vitamin $\mathrm{C}$ changes to the ascorbate radical. Pairs of ascorbate radicals react rapidly to form one molecule of ascorbate and one molecule of dehydroascorbate. dehydroascorbate is not having antioxidant properties. Dehydroascorbate change into ascorbate by addition of two electrons. Finally in presence of oxidoreductase, two electrons have been added to the dehydroascorbate. Scheme 4 (Oh, et al., 2010).

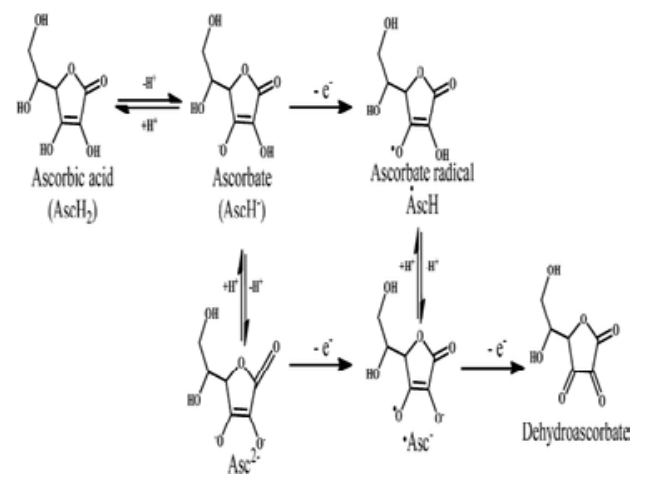

Scheme 4 Mechanism of radical scavenging activity of ascorbic acid

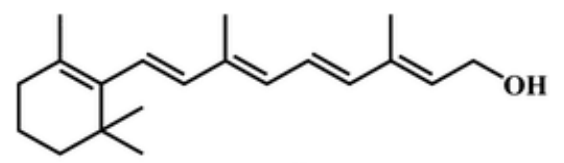

3

Picture: 3 Vitamin A 3.

Antioxidant potential of vitamin A 3 protects lipids against rancidity. (Monaghan and Schmitt,1932). While consider structural and metabolic characteristics Vitamin A is relation to heart diseases(Tesoriere, et 
al.,1997). This has vital antioxidant contribution in protecting low density lipid against copper-stimulated oxidation. (Scheme5). (Tesoriere, et al., 1997).

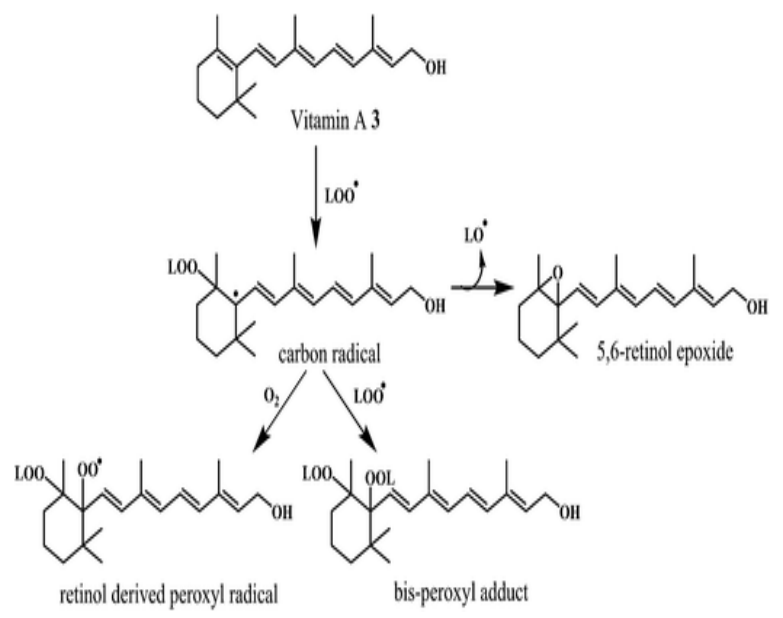

Scheme 5 Mechanism of radical scavenging activity of vitamin A

\section{Bioflavonoids}<smiles>O=C1CC(c2ccccc2)Oc2ccccc2C1=O</smiles>

Picture:4 Flavonol 4, Picture:5 flavone 7 , Picture:6 flavonolols 10, Picture:7 flavan-3-ols 12, Picture:8 flavonone 15, Picture:9 anthocyanidin 18, Picture:10 isoflavone 21

Bioflavonoids are found in G.edulis. This antioxidant is found naturally as benzo- $\gamma$-pyran derivatives which have strong free radical-scavenging activity (Armida, et al.,2005). These compounds are widely distributed in Vegetables as well as fruits and having protective mechanisms against DNA damage induced by the hydroxyl radicals (Nijveldt, et al., 2001). chelating metal ions especially iron and copper are involved with that protective mechanisms as prevent the formation of ROS ( Nijveldt, et al., 2001).

Flavanol compound is one of Quercetin 5 that is protected the DNA from oxidative damage resulting from attach of $\mathrm{O}_{2} \cdot{ }^{\cdot-} \mathrm{OH}$ and $\mathrm{H}_{2} \mathrm{O}_{2}$ on the DNA oligonucleotides. Scheme 6 (Jun, et al., 2007). Quercetin has shown opposite effects on DNA damage in presence of cupric ion. Scheme7 (Jun T et al.,2007). Quercetin 
Umakanthan Ganeshamoorthy; Effect of Different Processing Conditions on Antioxidant Activity of Gracilaria Edulis(Rhodophyseae) in Sri Lanka. Journal of Biomedical Engineering and Medical Imaging, Volume 6, No 5, October (2019), pp 64-90

enhances the damage to DNA by ROS in its high concentration $(\geq 25 \mu \mathrm{M})$. Quercetin gives a protective role in its low concentration $(\leq 25 \mu \mathrm{M})$. Therefore it is very important matter to consider chelating metal ions, such as copper or iron in the quercetin and other bioflavonoids activity.
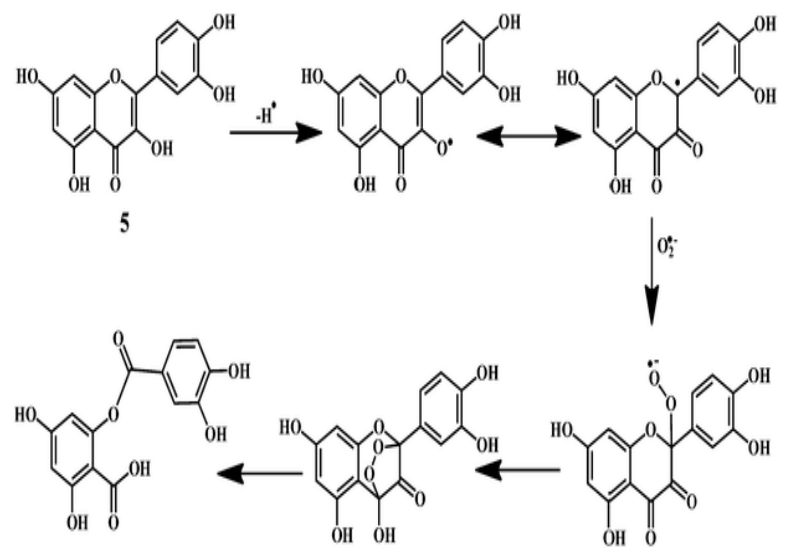

Scheme: 6 Mechanism of superoxide anion radical scavenging activity of quercetin

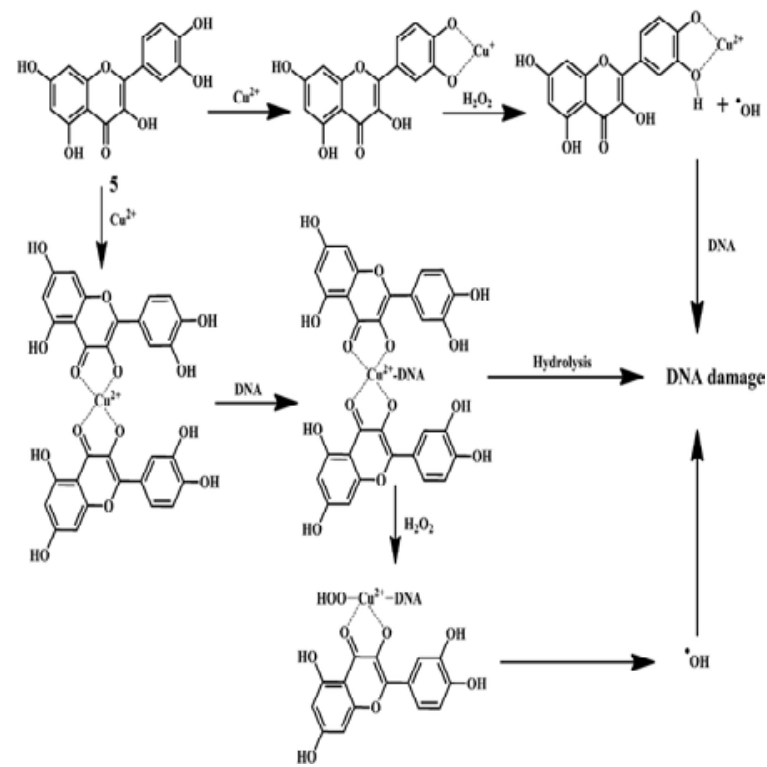

Scheme: 7 Mechanism of DNA damage induced by quercetin copper complex.

Antioxidant activity of pigment of Rhodophyta is Anthocynidine which is under class of flavonoids. Its effectives depend on inhibition of the lipid oxidation and its metal ion-chelating activity (Scheme 8) and also free-radical scavenging activity (Scheme 9). Radical-scavenging activity of anthocynidines determine by its three structural group such are ortho-dihydroxy structure in the B-ring, double bond in conjugation and 4-oxofunction in the C-ring (Miguel, el al.,2011). Flavonoids form different complexes with metal ions by hydroxyl groups in ortho position in the B-ring or using the 3- or 5-hydroxyl and 4-ketosubstituents. (Miguel, el al., 2011). 


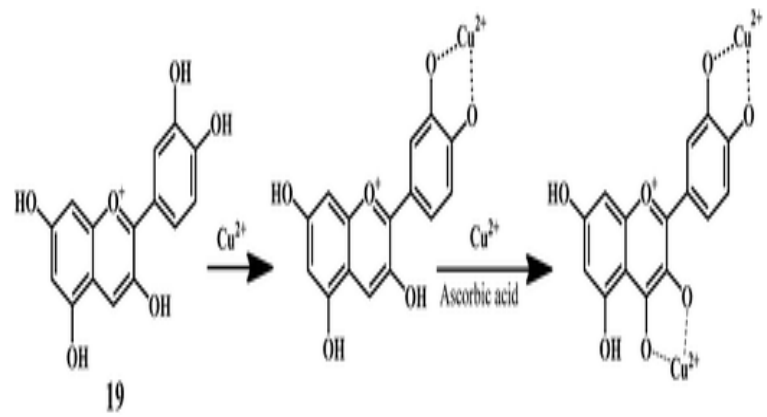

Scheme: 8 Metal ion $\left(\mathrm{Cu}^{2+}\right)$ chelating activity of anthocynidine (cynidin 19)

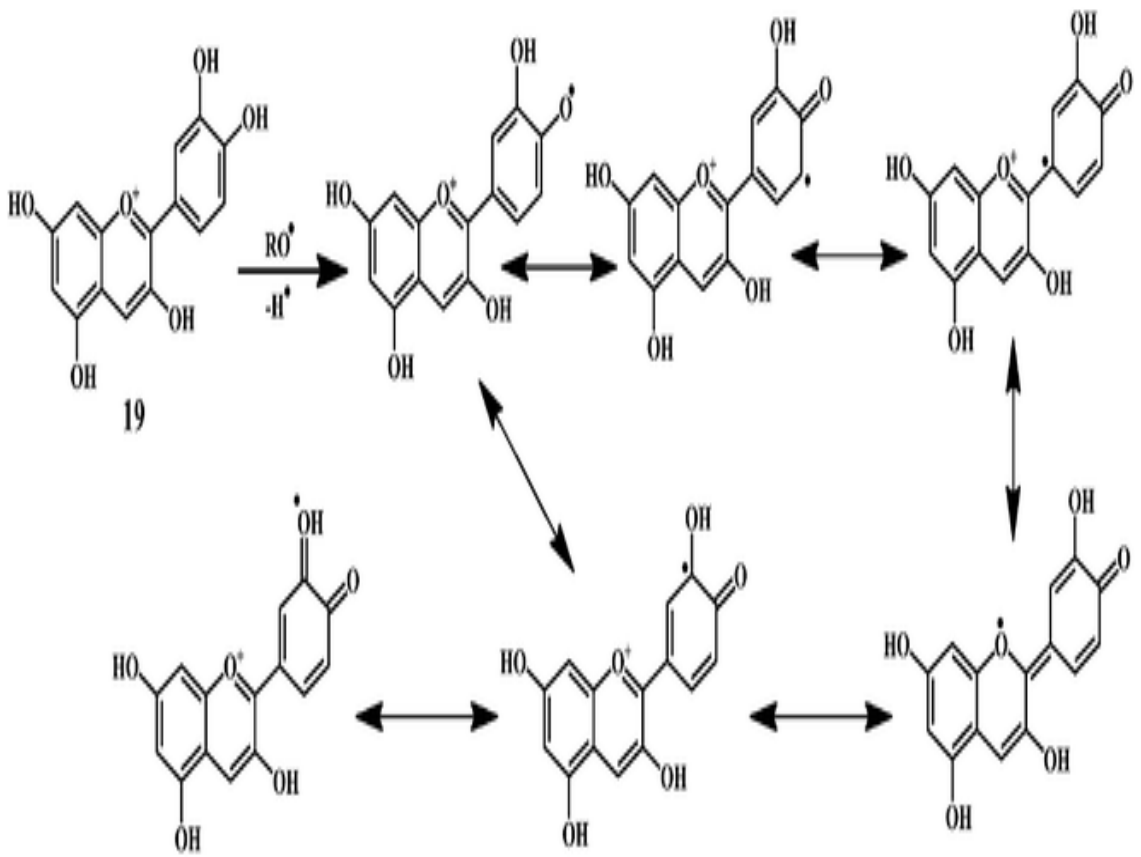

Scheme: 9 Mechanism of radical scavenging activity of cynidin

While consider Scheme 9, Anthocynidins donate an electron to a free radical of $\mathrm{OH}$ group attach in phenol ring for free radical inactivation (Acker, et al., 1996). In this process polyphenolic reducing agent changes to an aroxyl radical which is more stability due to its resonance effect rather than free radical reduced. Termination of damaging oxidative chain reactions takes place in overall reactions.

Carotenoid is one of the pigments present in Rhodophyta. This antioxidant is lipid soluble phytonutrients. $\beta$-carotene 25 and Lycopene 24 are main carotenoids among its group (Mueller, et al., 2011). The synthesis of carotenoids 26-29 from phytoene 25 was shown in Scheme 10. Carotenoids scavenge ROS lowerly than peroxyl radicals. Peroxyl radicals damage the lipids presence in cell wall in the lipid peroxidation process. This damage can be prevented by Scavenging of peroxyl radicals (Mueller, et al., 2011). In the carotenoids, long unsaturated alkyl chains form them highly lipophilic. Carotenoids react with peroxyl radicals to form resonance stabilized carbon-centered radical adducts for peroxyl radicals deactivation. 


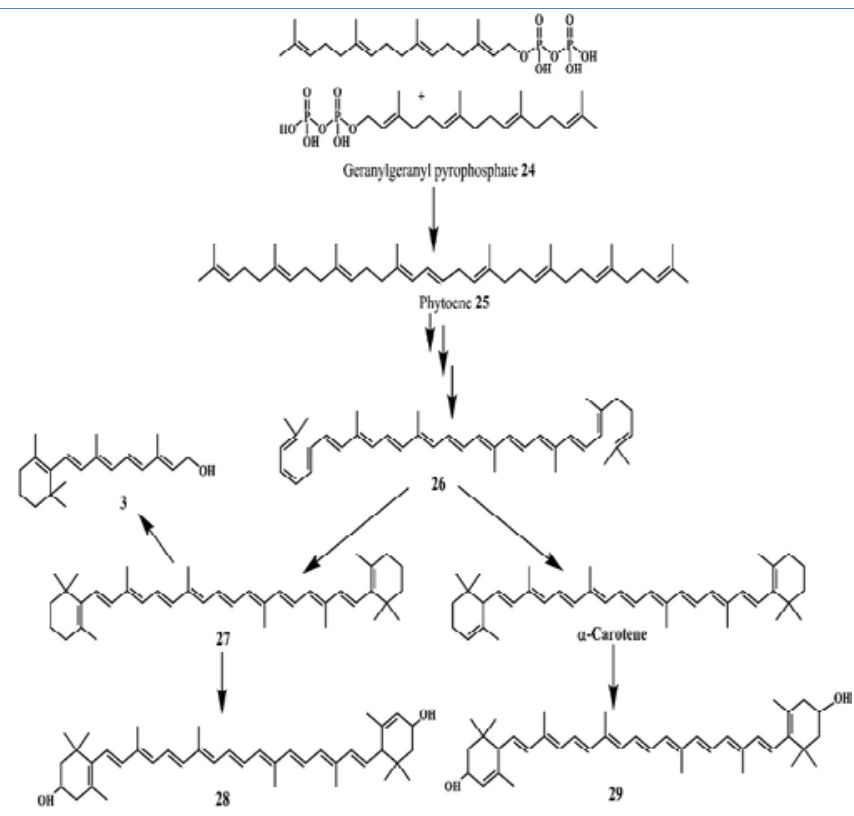

Scheme: 10 Biosynthetic pathway for the synthesis of carotenoids 26-29

Lycopene 24 is also found in vegetables and fruits. This has prominent antioxidant activity. Lycopene Conjugated double bonds donate the singlet oxygen quenching ability. This ability is comparatively higher than $\alpha$-tocopherol 1 or $\beta$-carotene 25 (Erhardt, et al., 2003). $\beta$-Carotene contain antioxidant ability due to its interaction with biological membranes and chemical structure (Erhardt, et al.,2003). (Z)-isomers of the $\beta$-carotene give antioxidant activity. In addition $\beta$-carotene-15, 15'-dioxygenase catalyzed cleavage gives two molecules of vitamin $A$ from $\beta$-carotene.

The table 1 was shown the absorbance of all different processed G.edulis. These results revealed all processed G.edulis sample were shown prominent antioxidant activity. In minitab-15 statistical software package, the absorbance, inhibition or hydrogen peroxide scavenging activity depend on the processing conditions of the G.edulis methanol extract was clearly resulted by Paired T-Test. Paired T-Test statistical test did tell about the difference between the different processing conditions of the methanol extract of the G.edulis $(p<0.05)$ and antioxidant activity. Which two factors were not independent factors such are depend on each other. While Hydrogen peroxide absorbance was decreased, the percentage scavenging of hydrogen peroxide or inhibition was increased and antioxidant activity was also increased. The methanolic extracts of the G.edulis was prepared keeping methanol as a standard. In Graph 1Pearson correlation was shown Antioxidant properties of all processed sample were been correlated to its absorbance. That means antioxidant compounds were presence of those sample. Here a hydrogen donor or electron donation was occurred efficiently. All different processed G.edulis methanol extract samples antioxidant properties were compared to the L-ascorbic acid which used as positive control. In the Table 2, boiled G.edulis sample was recorded comparatively highest antioxidant properties than other processed G.edulis sample due to less leaching seaweeds phytochemical constitutions. Antioxidant activity of this G.edulis depends on its presence of bioactive compounds. Absorbance was highly in steamed followed by dried, microwaved, fresh and boiled G.edulis respectively due to presence of low amount bioactive antioxidant compounds basis. Hence $\mathrm{H}_{2} \mathrm{O}_{2}$ scavenging activity or antioxidant activity was 
highly in boiled G.edulis, followed by fresh, microwaved and dried respectively. L-ascorbic acid was used as Positive control and its antioxidant activity was higher than dried and steamed but relatively lowers than microwaved fresh and boiled G.edulis. Antioxidant activity of Boiled G.edulis was recorded higher activity than other processed G.edulis followed by fresh, microwaved, dried and steamed respectively. Steamed G.edulis was lowest antioxidant activity than others. Scavenging effects of the steam, dried, microwaved, fresh and boiled were increased up to $53.125 \%, 68.75 \%, 82.03125 \%, 84.375 \%$ and $92.1875 \%$ at $100 \mu \mathrm{g} / \mathrm{ml} \mathrm{G.edulis} \mathrm{samples} \mathrm{methanol} \mathrm{extract.} \mathrm{In} \mathrm{Graph2,} \mathrm{There} \mathrm{was} \mathrm{strong} \mathrm{negative} \mathrm{correlation}$ between scavenging ability on $\mathrm{H}_{2} \mathrm{O}_{2}$ radical and absorbance of total antioxidant compounds of different processed G.edulis and positive correlation between antioxidant activity and the antioxidant compounds presence in different processed G.edulis. Excellent antioxidant effect was recorded at boiled one.

\section{Conclusion}

This research paper finding was indicated that the processing conditions significantly influenced the antioxidant activity of G.edulis in order to find the most potent functional processed G.edulis. Antioxidant activity of different processed G.edulis was a better knowledge of how these processing conditions affects the antioxidant compounds. Processing parameters such as heat was influenced the loss of health related antioxidant compounds and phytochemicals. Since from ancient times people may be known heat processing was invariably leads to a loss of antioxidant properties a compromise must be reached between nutrition and palatability. But this present research study revealed that a boiling of G.edulis was reduced processing time and to less leaching of phytochemicals or antioxidant compound. The antioxidant activity of different processed G.edulis was determined rapidly and accurately by quick method of $\mathrm{H}_{2} \mathrm{O}_{2}$ scavenging activity, which method was conducted successfully for algae with methanolic extraction. While scavenging the $\mathrm{H}_{2} \mathrm{O}_{2}$ free radical by phytochemical in the G.edulis methanolic extract, antioxidant activity was measured by absorbance of spectrophotometer. Antioxidants were been varied due relative antioxidant content such as flavanols, biflavanoids, pigments, fiber, mineral and vitamins. The reason behind the antioxidant of boiled G.edulis has greater potential to reduce free radical in the human body Where the expose high antioxidant in G.edulis caused removal or reduction of free radical in body highly. Therefore these findings were concluded antioxidant content and basic nutritional information of the different processed G.edulis samples.

Furthermore the antioxidant activity was higher in boiled G.edulis followed by dried, microwaved, fresh, dried and steam respectively. Finally Boiled G.edulis sample was recorded prominent antioxidant activity due to leaching of less antioxidant compounds. From this research results boiled G.edulis was a good antioxidant activity rather than other processed G.edulis and this processing method was recommended. In future these research findings were used for functional product development incorporation of boiled G. edulis into bakery Products and supported to predict new type of food production in the business market in Sri Lanka. Thus the consumption of G.edulis food products may result good health promoting benefits either therapy or human nutrition to save the human life from degenerative diseases. 
Umakanthan Ganeshamoorthy; Effect of Different Processing Conditions on Antioxidant Activity of Gracilaria Edulis(Rhodophyseae) in Sri Lanka. Journal of Biomedical Engineering and Medical Imaging, Volume 6, No 5, October (2019), pp 64-90

\section{REFERENCE}

[1] Acker S. A. van, van den Berg D. J., Tromp M. N., Griffioen D. H., Bennekom W. P. van, Vijgh W. J. van der and Bast A., (1996). Structural aspects of antioxidant activity of flavonoids. Free Radical Biol. Med, 20, 331-342.

[2] Akoh, C. C. and Min, B. D. (1997). Food Lipid Chemistry. In: NutritionBiotechnology Marcel Dekker Inc., New York.

[3] Al-Azzawie, H. F. and Mohamed-Saiel, S. A. (2006). Hypoglycemic and antioxidant effect of oleuropein in alloxan-diabetic rabbits. Life Science, 78, 1371-1377.

[4] Albertus J. Smit. (2004). Medicinal and pharmaceutical uses of seaweed natural products: A review. Authors; Authors and affiliations. Journal of Applied Phycology. 16, 245-262.

[5] Amic, D., Davidovic-Amic, D. and Beslo, N. (2003). Trinajstic, Structure-radical scavenging activity relationship of flavonoids. Croatia Chemica Acta, 76, (1), 55-61.

[6] Amin Ismail \& Tan Siew Hong.,(2002). Antioxidant Activity of Selected Commercial Seaweeds. Department of Nutrition and Health. Mal J Nutr 8(2): 167-177.

[7] Amin Ismail \& Tan Siew Hong.,(2002). Antioxidant activity of selectedcommercial seaweeds, Mal J Nutr 8(2), pp.167 -177.

[8] Armida, T., Maurizio, T., Andrea T. and Sergio, B., (2005). Copper(II)-Quercetin complexes in aqueous solutions: Spectroscopic and kinetic properties. J. Mol.Struct. 44, 759-766.

[9] Arnold, T M. and Targett, N. M., (1998). Predicting the effects of brown algal phlorotannins on marine herbivores in tropical and temperate oceans. Journal of Phycology, 34, 195-205.

[10] Arthur C. Mathieson, Judith R. Pederson, Christopher D. Neefus, Clinton J. Dawes, and Troy L. Bray. Mathieson., (2000). Atlantic. Multiple assessments of introduced seaweeds in the Northwest Atlantic. Journal of Marine Science, 65: 730-741.

[11] Aruoma, I. O., (1999). Antioxidant action of plant foods. Use of oxidative DNA damage, as a tool for studying antioxidant efficacy. Free Radical Research, 30, 419-427.

[12] Bandoniene, D. and Murkovic, M., (2002). On-line HPLC-DPPH screening method for evaluation of radical scavenging phenols extracted from apples (Malus domestica L.). Journal of Agricultural and Food Chemistry, 50, 2482-2487.

[13] Bansemir, A., Blume, M., Schroder, S. and Lindequist, U., (2006). Screening of cultivated seaweeds for antibacterial activity against fish pathogenic bacteria. Aquaculture, 252, 79-84.

[14] Bodamyali, T., Stevens, C. R., Blake, D. R. and Winyard, P. G. (2000). Reactive oxygen/nitrogen species and acute inflammation: a physiological process. In: Winyard, P. G. Blake, D. R. and Evans, C. H., Eds. Free radicals and inflammation.Basel, Switzerland: Birkhauser pp. 11-19. 
[15] Bouhlal, R.-Haslin, C-Chermann, J.C.-Colliec-Jouault, S.-Sinquin, C-Simon, G. -Cerantola, S.-Riadi, and HBourgougnon, N. (2011). Antiviral activities of sulfated Polysaccharides isolated from Sphaerococcuscoronopifolius (Rhodophyta, Gigartinales) andBoergeseniellathuyoides (Rhodophyta, Ceramiales). In Marine Drugs, vol. 9: p. 1187-1209.

[16] Chanda, S.,(2010), Seaweeds: A novel, untapped source of drug from sea to combat infectious diseases, Current Research, Technology and Education Topics in Applied Microbiology \& Microbial Biotechnology, Vol 1,pp.473-480.

[17] Chandini, S. K., Ganesan, P. and Bhaskar N., (2008). In vitro antioxidant activities of three selected brown seaweeds of India, Food Chemistry. 107, 707-713.

[18] Chengkui, Z., Tseng, C.K., Junfu, Z., and Chang, C.F., (1984).Chinese seaweeds in herbal medicine. Hydrobiologia , 116-117:152-154.

[19] Cheung L.M., Cheung P.C.K. and Ooi V.E.C., (2003). Antioxidant activity and total phenolics of edible mushroom extracts, FoodChem. 81, 249-255.

[20] Chew, Y. L., Lim, Y. Y., Omar, M. and Khoo, K. S., (2008). Antioxidant activity of three edible seaweeds from two areas in South East Asia. LWT, 41, 1067-1072.

[21] Chiewchan, N., Praphraiphetch, C. and Devahastin, S., (2010). Effect of pretreatment on surface topographical features of vegetables during drying. Journal of Food Engineering, 101, 41-48.

[22] Cox, S., Abu-Ghannam, N. and Gupta, S., (2010). An assessment of the antioxidant and antimicrobial activity of six species of edible Irish seaweeds. International Food Research Journal, 17, 205-220.

[23] Duan, X. J., Zhang, W. W., Li, X. M. and Wang, B. G., (2006). Evaluation of antioxidant property of extract and fractions obtained from a red alga, Polysiphonia urceolata. Food Chemistry, 95, 37-43.

[24] Erhardt J. G., Meisner C., Bode J. C. and Bode C., (2003). Lycopene, $\beta$-carotene, and colorectal adenomas. Am. J. Clin.Nutr. 78, 1219-1224.

[25] Fisch, K. M., Böhm, V., Wright, A. D. and König, G. M. (2003). Antioxidative meroterpenoids from the brown alga Cystoseira crinite. Journal of Natural products.66, 968-975.

[26] Fujiwara-Arasaki, T., N. Mino, and M. Kuroda., (1984). The protein value in human nutrition of edible marine algae. Journal of Applied Phycology. 11:231-239.

[27] Gahler, S., Otto K. and Bohm, V., (2003). Alterations of vitamin C, total phenolics, and antioxidant capacity as affected by processing tomatoes to different products. Journal of Agriculture and Food Chemistry, 51, 7962-7968.

[28] Ganesan, P., Kumar, C. S. and Bhaskar, N., (2008). Antioxidant properties of methanol extract and its solvent factions obtained from selected Indian red seaweeds. Bioresource Technology, 99, 2717-2723.

[29] Gonzalez del Val, A., Platas, G., Basilo, A., Cabello, A., Gorrochategui, J., Suay, I., Vicente, F., Portillo, E., Jimenez del Rico, M., Garcia Reina, G. and Pelez, F., (2001). Screening of antimicrobial activities in red, 
Umakanthan Ganeshamoorthy; Effect of Different Processing Conditions on Antioxidant Activity of Gracilaria Edulis(Rhodophyseae) in Sri

Lanka. Journal of Biomedical Engineering and Medical Imaging, Volume 6, No 5, October (2019), pp 64-90

green and brown macroalgae from Gran Canaria (Canary Islands, Spain). International Journal of Microbiology, 4, 35-40.

[30] Gough D.R and Cotter, T. G., (2011). Hydrogen peroxide: a Jekyll and Hyde signaling molecule.Cell Death Dis, 2, 213.

[31] Halliwell, B. and Gutteridge, J. M., (1990). Role of free radicals and catalytic metal ions in human diseases: an overview. Methods in Enzymology, 186, 25-30.

[32] Harbourne, J. B., (1994). The Flavonoids: Advances in Research Since 1986. London, UK: Chapman and Hall.

[33] Haslam, E., (1989). Plant Polyphenols: Vegetable Tannins Revisited. Cambridge University Press, Cambridge, UK.

[34] Herrmann, K., (1989). Occurrence and content of hydroxycinnamic and hydroxybenzoic acid compounds in food. CRC Critical Reviews in Food Science and Nutrition, 28, 315-347.

[35] Hwang Pai-An, Wu Chwen-Herng, Gau Shu-Yun, Chien Shih-Yung and Hwang Deng-Fwu., (2010). Antioxidant and immune-stimulating activities of hot-water extract from seaweed Sargassum hemiphyllum, Journal of Marine Science and Technology, 18(1): pp. 41-46.

[36] Ismail, A., Marjan, Z. M. and Foong, C. W., (2004). Total antioxidant activity and phenolic content in selected vegetables. Food Chemistry, 87, 581-586.

[37] Ito K and Hori K., (1989). Seaweed: Chemical composition and potential food uses. Food Rev Int 5:101144.

[38] Jadhav, S.J. Nimbalkar, S.S. Kulkarni, A.D. \& Madhavi, D.L., (1995). Lipid Oxidation In Biological and Food Systems. In: Food Antioxidants. Madhavi DL, Deshpande SS \& Salunkhe DK (eds). New York.

[39] Jun, T., Liancai Z. and Bochu, W., (2007). Free radicals, natural antioxidants and their mechanisms. Int. J. Pharmacol., 3, 19-26.

[40] Kahkonen, M. P., Hopia, A. I., Vuorela, H. J., Rauha, J. P., Pihlaja, K., Kujala, T. S., (1999). Antioxidant activity of plant extracts containing phenolic compounds. Journal of Agricultural and Food Chemistry, 47, 39543962.

[41] Kasi Pandima Devi, Natarajan Suganthy, Periyanaina Kesika and Shanmugaiahthevar Karutha Pandian., (2008). Bioprotective properties of seaweeds: In vitro evaluation of antioxidant activity and antimicrobial activity against food borne bacteria in relation to polyphenolic content", $8^{\text {th }}$ Ed., BMC Complementary and Alternative Medicine,pp38.

[42] Kawanishi, S., Hiraku, Y., Murata, M. and Oikawa, S., (2002). The role of metals in site-specific DNA damage with reference to carcinogenesis. Free Radical Biology and Medicine, 32, 822-832. 
[43] Kolanjinathan, K. and Saranraj, P., (2014). Pharmacological efficacy of marine seaweed Gracilaria edulis extracts against clinical pathogens. Global Journal of Pharmacology. 8(2):268-274.

[44] Koruk M, Taysi S, Savas MC, Yilmaz O, Akcay F and Karakok M., ( 2004). Oxidative stress and enzymatic antioxidant status in patients with nonalcoholic steatohepatitis. Annals of clinical and laboratory science, 34:57-62.

[45] Kuda, T., Kunii, T., Goto, H., Suzuki, T. and Yano, T., (2007). Varieties of antioxidant and antibacterial properties of Ecklonia stolonifera and Ecklonia kurome products harvested and processed in the Noto peninsula, Japan. Food Chemistry, 103, 900-905.

[46] Laguerre, M., Lecomte, J. and Villeneuve, P., (2007). Evaluation of the ability of antioxidants to counteract lipid oxidation: Existing methods, new trends and challenges. Progress in Lipid Research, 46, 244-282.

[47] Layse C F. de Almeida, Heloina de S. Falcao and Leonia M. and Batista (2011). Bioactivities from Marine Algae of the Genus Gracilaria. Int J Mol Sci. 12(7): 4550-4573.

[48] Lim, S. N., Cheung, P. C. K., Ooi, V. E. C. and Ang, P. O., (2002). Evaluation of antioxidative activity of extracts from a brown seaweed, Sargassum siliquastrum. Journal of Agricultural and Food Chemistry, 50, 3862-3866.

[49] Lim, Y. Y. and Murtijaya, J., (2007). Antioxidant properties of Phyllanthus amarus extracts as affected by different drying methods. LWT Food Science and Technology, 40, 1664-1669.

[50] Lu, F. and Foo, L. Y., (1995). Phenolic antioxidant components of evening primrose.

[51] Madhusudan, C., S. Manoj, K. Rahul and C.M. Rishi., (2011). Seaweeds: A diet with nutritional, medicinal and industrial value. Journal of Medicinal plant 52, 153-157.

[52] Manach, C., Scalbert, A., Morand, C., Rémés, C. and Jiménez, L., (2004). Polyphenols: food sources and bioavailability. American Journal of Clinical Nutrition, 79, 727-747.

[53] Mat'es J. M., (2000). Toxicology, Effects of antioxidant enzymes in the molecular control of reactive oxygen species toxicology. 153, 83-104.

[54] Matsukawa, R., Dubinsky, Z., Kishimoto, E., Masak, K., Masuda, Y., Takeuchi, T., Chihara, M., Yamamoto, Y., Niki, E. and Karube, I., (1997). A comparison of screening methods for antioxidant activity in seaweeds. Journal of Applied Phycology, 9, 29-35.

[55] Meenakshi, S. D. and Manicka Gnanambigai., (2009).Total flavonoid and invitro antioxidant activity of two seaweeds of Rameshwarem coast. Global journal of pharmacology. 3(2), 59-62.

[56] Micheline Cristiane Rocha de Souza, Cybelle Teixeira Marques and Celina Maria Guerra., (2007). Antioxidant activities of sulfated polysaccharides from brown and red seaweeds. J Appl Phycol. 19(2): 153-160.

[57] Miguel M. G., ( 2011). Anthocyanins: Antioxidant and/or anti-inflammatory activities. J. Appl. Pharm. Sci, 01, 07-15. 
Umakanthan Ganeshamoorthy; Effect of Different Processing Conditions on Antioxidant Activity of Gracilaria Edulis(Rhodophyseae) in Sri Lanka. Journal of Biomedical Engineering and Medical Imaging, Volume 6, No 5, October (2019), pp 64-90

[58] Miller HE, Rigelhof F, Marquart L, Prakash A. and Kanter M., (2000). Antioxidant content of whole grain breakfast cereals, fruits and vegetables. J Am Coll Nutr,19:312S-319S.

[59] Miller, H.E., Rigelhof, F., Marquart, L., Prakash, A., and Kanter, M., (2000). Cereal Foods World, 45(2), 5963.

[60] Monaghan B. R. and Schmitt F. O., (1932). The effects of carotene and of vitamin A on the oxidation of linoleic acid. J. Biol. Chem. 96,387-395.

[61] Morli'ere P., Patterson L. K., Santos C. M. M., Silva A. M. S., Mazi'ere J., Filipe P., Gomes A., Fernandes E., Garciah M. B. Q. and Santusc R., (2012). The dependence of $\alpha$-tocopheroxyl radical reduction by hydroxy2,3-diarylxanthones on structure and micro-environment.Org. Biomol. Chem.10, 2068-2076.

[62] Moure, A., Cruz, J. M., Franco, D., Dominguez, J. M., Sineiro, J., Dominguez, H., Nunez, M. J. and Parajo, J. C., (2001). Natural antioxidants from residual sources. Food Chemistry, 72, 145-171.

[63] Mueller L. and Boehm V., (2011). Antioxidant Activity of $\beta$-Carotene Compounds in Different in Vitro Assays.Molecules, 16, 1055-1069.

[64] Naczk, M. and Shahidi, F., (2004). Extraction and Analysis of Phenolics in Food. Journal of Chromatography, 1054, 95-111.

[65] Nakamura, Y., Watanabe, S., Miyake, N., Kohno, H. and Osawa, T., (2003). Dihydrochalcones: evaluation as novel radical scavenging antioxidants. Journal of Agricultural and Food Chemistry, 51, 3309-3312.

[66] Nijveldt RJ, van Nood E, van Hoorn DEC, Boelens PG, van Norren K. and van Leeuwen PAM.,( 2001). Flavonoids: a review of probable mechanisms of action and potential applications. J Clin Nutr. 74(4): 418425 .

[67] Oh C., Kim M. Li, E., Park J. S., Lee J., Ham S. W. and Bull., (2010). Antioxidant and radical scavenging activities of ascorbic acid derivatives conjugated with organogermanium.Korean Chem. Soc. 31, 35133514.

[68] Ong In A. S. H., Niki E. and Packer L. (Eds), Nutrition, Lipids, Health, and Disease Champaign, American Oil Chemists Society.(pp. 86-95).

[69] Pisani, P. Bray, F. and Parkin, D.M. Estimates of the world-wide prevalence of cancer for 25 sites in the adult population. Int J Cancer 97:71-81.

[70] Plaza, M., Santoyo, S. Jaime, L., García-Blairsy Reina, G., Herrero, M., Senoráns, F.J. and Ibánez, E., (2009). Screening for bioactive compounds from algae. Journal of Pharmaceutical and Biomedical Analysis, 51 (2), 450-455.

[71] Ragan, M. A. and Glombitza, K. W., (1986). Phlorotannins, brown algal polyphenols. In: Hellebustad, JA, Craigie, JS (Eds), Handbook of Phycological Methods, Vol II. Cambridge University Press, Cambridge, (pp. 129-241). 
[72] Reaven, P. D. and Witzum, J. L., (1996). Oxidised LDL in atherogenesis. Role of dietary modification. Annual Review of Nutrition, 16, 51-71.

[73] Rungapamestry, V., Duncan, A. J., Fuller, Z. and Ratcliffe, B., (2007). Effect of cooking Brassica vegetables on the subsequent hydrolysis and metabolic fate of glucosinolates. Proceedings of the Nutrition Society, $66,69-81$.

[74] Russo, N., Toscano, M. and Uccella, N., (2000). Semiempirical molecular modeling into quercetin reactive site: structural, conformation, and electronic features. J. Agric. Food Chem. 48 (8), 3232-3237.

[75] Sachidanandame, K., Fagan, S. C. and Ergul, A. (2005). Oxidative stress and cardiovascular disease: antioxidants and unresolved issues. Cardiovascular drug reviews, 23, 115-132.

[76] Schwarz K, Bertelsen G, Nissen LR, Gardner PT, Heinonen MI, Hopia A, Huynh-Ba T, Lambelet P, McPhail D, Skibsted LH and Tijburg L., (2001).Investigation of plant extracts for the protection of processed foods against lipid oxidation. Comparison of antioxidant assays based on radical scavenging, lipid oxidation and analysis of the principal antioxidant compounds. Eur Food Res Technol., 212:319-328.

[77] Shahidi, F. (2009). Nutraceuticals and functional foods: Whole versus processed foods. Trends in Food Science and Technology, 20 (9), 376-387.

[78] Shahidi, F. and Zhong, Y., (2008). Bioactive Peptides. Journal of AOAC International, 91, 914-931.

[79] Shahidi, P. K. J. and Wanasundara, P. D., (1992). Phenolic antioxidants. Critical Reviews in Food Science and Nutrition, 32 (1), 67-103.

[80] Shan, B., Cai, Y. Z., Brooks, J. D. and Corke, H., (2007). The in vitro antibacterial activity of dietary spice and medicinal herb extracts. International Journal of Food Microbiology, 117, 112-119.

[81] Shon, M. Y., Kim, T. H. and Sung, N. J., (2003). Antioxidants and free radical scavenging activity of Phellinus baumii (Phellinus of Hymenochaetaceae) extracts. Food Chemistry, 82, 593-597.

[82] Shukla, V. K., Wanasundara, P. K. and F. Shahidi., (1997). Natural antioxidants from oilseeds. In: (Shahidi, F. eds), Natural antioxidants: Chemistry, health effects, and applications. AOCS Press, Champaign, IL. pp. 97-132.

[83] Skibola, C., (2004).The effect of Fucus vesiculosus, an edible brown seaweed, upon menstrual cycle length and hormonal status in three pre-menopausal women: a case report. BMC Complementary and Alternative Medicine 4, 10-17.

[84] Stone J. R. and Yang S., (2006). Hydrogen Peroxide: A Signaling Messenger.Antioxid. Redox Signaling, 8, 243-270.

[85] Takamatsu, S., Hodges, T. W., Rajbhandari, I., Gerwick, W. H., Hamann, M. T. and Nagle, D. G., (2003). Marine natural products as novel antioxidant prototypes. Journal of Natural Products, 66, 605-608.

[86] Tesoriere L, Fazzari M, Angileri F, Gentile C. and Livrea M. A., ( 2008). In vitro digestion of betalianic foods. Stability and bioaccessibility of betaxanthins and betacyanins and antioxidative potential of food digesta. J Agric Food Chem. 56(22): 10487-92. 
Umakanthan Ganeshamoorthy; Effect of Different Processing Conditions on Antioxidant Activity of Gracilaria Edulis(Rhodophyseae) in Sri Lanka. Journal of Biomedical Engineering and Medical Imaging, Volume 6, No 5, October (2019), pp 64-90

[87] Turkmen, N., Sari, F. and Velioglu, Y. S., (2005). The effect of cooking methods on total phenolics and antioxidant activity of selected green vegetables. Foodchemistry.93,713-718.

[88] Umakanthan, G., Vinobaba, P., Radampola, K., (2016). Phytochemical constitution of cultured G.edulis from the east coast of Batticaloa District, in Sri Lanka. Proceedings of $1^{\text {st }}$ International conference at Trinco campus, Eastern University, Sri Lanka Konesapuri, Nilaveli Sri Lanka.

[89] Valentão, P., Fernandes, E., Carvalho, F., Andrade, P. B., Seabra, R. M. and Bastos, M. L., (2002). Antioxidative properties of Cardoon (Cynara cardunculus L.) infusion against superoxide radical, hydroxyl radical and hypochlorous acid. Journal of Agricultural and Food Chemistry, 50, 4989-4993.

[90] Valko M, Leibfritz D, Moncol J, Cronin MT, and Mazur M., (2007). Free radicals and antioxidants in normal physiological functions and human disease. Int J Biochem Cell Biol 1: 44-84.

[91] Valko M., Rhodes C. J., Moncol J., Izakovic M. and Mazur M., (2006). Free radicals, metals and antioxidants in oxidative stress-induced cancer. Chem.-Biol. Interact.160, 1-40.

[92] Varahalarao vadlapudi and K. Chandrashekar Naidu., (2010). In vitrobioevaluationofantioxidant activities of selected marine algae, Journal Of Pharmacy Research 3(2), 2010, pp.329-331.

[93] Vimala, S., Norhanom, A. W. and Yadav, M., (1999). Anti-tumour promoter activity in Malaysian ginger rhizobia used in traditional medicine. British Journal of Cancer, 80,110-116.

[94] Volden, J., Borge, G. I. A., Hansen, M., Wicklund, T. and Bengtsson, G. B., (2009). Processing (blanching, boiling and steaming) effects on the content of glucosinolates and antioxidant-related parameters in cauliflower (Brassica oleracea L. ssp. botrytis). LWT Food Science and Technology, 42, 63-73.

[95] Volden, J., Borge, G. I. A., Hansen, M., Wicklund, T. and Bengtsson, G. B., (2009). Processing (blanching, boiling and steaming) effects on the content of glucosinolates and antioxidant-related parameters in cauliflower (Brassica oleracea L. ssp. botrytis). LWT Food Science and Technology, 42, 63-73.

[96] Wallace, G. and Fry, S. C., (1994). Phenolic components of the plant cell wall. International Review of Cytology, 151, 229-267.

[97] Watchtel-Galor, S., Wong, K. W. and Benzie, I. F. F., (2008). The effect of cooking on Brassica vegetables. Food Chemistry, 110, 706-710.

[98] Waterman, P. G. and Mole, S., (1994). Analysis of Phenolic Plant Metabolites. In: Methods in Ecology. Blackwell Scientific Publications, Oxford, UK.

[99] Witting P. K., Upston J. M. and Stocker R., (1997). Role of $\alpha$-Tocopheroxyl Radical in the Initiation of Lipid Peroxidation in Human Low-Density Lipoprotein Exposed to Horse Radish Peroxidase. Biochemistry, 36, 1251-1258.

[100] Wright, J.S., Johnson, E.R. and Di Labio, G.A., (2001). Predicting the activity of phenolic antioxidants: theoretical method, analysis of substituent effects, and application to major families of antioxidants. J. Am. Chem. Soc. 123 (6), 1173-1183. 
[101] Yamaguchi, T. Takamura, H. Matoba, T. \& Terao, J., (1998). HPLC method for evaluation of the free radicalscavenging activity of foods by using 1, 1-diphenyl-2-picrylhydrazyl. Biosci Biotechnol Biochem 62:1201-1204.

[102] Yu, L., Halet, S., Perret, J. and Harris, M. (2002). Antioxidant properties of hard winter wheat extracts. Food Chemistry, 78, 457-461.

[103] Yuan, Y. V., Carrington, M. F. and Walsh, N. A. (2005). Extracts from dulse (Palmaria palmata) are effective antioxidants and inhibitors of cell proliferation in vitro. Food and Chemical Toxicology, 43, 1073-1081.

[104] Zhang, D. and Hamauzu, Y. (2004). Phenolics, ascorbic acid, carotenoids and antioxidant activity of broccoli and their changes during conventional and microwave cooking. Food Chemistry, 88, 503-509. 